Portland State University

PDXScholar

\title{
In the Wake of the Gulf War: Assessing Family Spending of Compensation Money in Sri Lanka
}

\author{
Michele Ruth Gamburd \\ Portland State University, b5mg@pdx.edu
}

Follow this and additional works at: https://pdxscholar.library.pdx.edu/anth_fac

Part of the Social and Cultural Anthropology Commons

Let us know how access to this document benefits you.

\section{Citation Details}

Gamburd, Michele Ruth, "In the Wake of the Gulf War: Assessing Family Spending of Compensation Money in Sri Lanka" (2003). Anthropology Faculty Publications and Presentations. 41.

https://pdxscholar.library.pdx.edu/anth_fac/41

This Post-Print is brought to you for free and open access. It has been accepted for inclusion in Anthropology Faculty Publications and Presentations by an authorized administrator of PDXScholar. Please contact us if we can make this document more accessible: pdxscholar@pdx.edu. 
Full title: In the wake of the Gulf War: assessing family spending of compensation money in Sri Lanka

Short title: In the wake of the Gulf War

Name of author: Michele Ruth Gamburd

Author's affiliation: Portland State University

\section{Author's contact information:}

\section{Postal address:}

Dr. Michele Gamburd

Anthropology Department

Portland State University

Portland, OR 97207-0751

\section{Street address:}

Dr. Michele Gamburd

Anthropology Department, 141 Cramer Hall

Portland State University

1721 SW Broadway

Portland, OR 97201

Phone: 503/ 725-3317

Fax: 503/ 725-3905

Email: gamburdm@pdx.edu 


\title{
IN THE WAKE OF THE GULF WAR: ASSESSING FAMILY SPENDING OF COMPENSATION MONEY IN SRI LANKA
}

Michele Ruth Gamburd

Portland State University

\begin{abstract}
:
Between 1997 and 2000, the United Nations Compensation Commission delivered US\$ 4000 apiece to roughly 87,000 Sri Lankan citizens who suffered displacement and loss of employment due to Iraq's military actions in Kuwait during the Gulf War. Using qualitative ethnographic data, this essay examines eleven case studies of Kuwait returnees in the village of Naeaegama, in southern Sri Lanka. Like the majority of Sri Lankans caught in the Gulf War, these returnees are women from poor rural families who worked as domestic servants in Kuwait. The essay compares how the eleven households have spent compensation money and migrants' remittances. Spending choices reveal a clear hierarchy of priorities: buying land and building a house, providing a dowry for unmarried women, and starting a viable business. These goals reflect family-based considerations, and use of the money illustrates the family's role as an economic as well as a social unit. The essay also explores the role of family in facilitating migration and depressing women's wages on the global market. Data reveal the local values, motives, and cultural contexts that shape individual and family decision-making on matters of finance and migration. Family choices are products of and adaptations to globalized contexts.
\end{abstract}

KEYWORDS: Sri Lanka, Gulf War, United Nations Compensation Commission, labor migration, remittances, household decision-making 


\section{IN THE WAKE OF THE GULF WAR: ASSESSING FAMILY SPENDING OF COMPENSATION MONEY IN SRI LANKA}

\section{INTRODUCTION}

The capitalist economy penetrates the very fabric of family life in the village of Naeaegama, ${ }^{1}$ a Sinhala-Buddhist settlement on the southwestern coast of Sri Lanka. ${ }^{2}$ For the past two decades, ever-growing numbers of women, both locally and nationally, have migrated to work as housemaids in Saudi Arabia, Kuwait, and the United Arab Emirates. Iraq's invasion of Kuwait in August 1990 displaced 100,000 Sri Lankans, over two-thirds of them housemaids. The United Nations Security Council found Iraq guilty of unlawfully invading its smaller oil-producing neighbor, and ordered Iraq to pay compensation to people who suffered losses due to its military actions. Delayed for over four years due to international sanctions on the sale of Iraqi oil, compensation finally reached successful applicants. Between 1997 and 2000, the United Nations Compensation Commission (UNCC) delivered US\$ 4000 each to roughly 87,000 Sri Lankan citizens, including thirteen women from Naeaegama.

This essay presents qualitative data on the goals and priorities influencing decision-making processes in the households of eleven of these Naeaegama Gulf War returnees. This essay's author, a cultural anthropologist, has collected ethnographic information for over a decade concerning how female migration patterns have affected family structures and gender relations in Naeaegama. The distribution of UNCC funds provides a unique opportunity to examine what households have done with a substantial amount of money received as a lump sum, and to compare this with spending patterns associated with migrants' wages. Since the majority of Sri Lankans caught in the Gulf War were women from poor rural families who worked as domestic servants in Kuwait, information from these particular households will shed light more generally on household priorities that govern savings and investment at the local level. The essay provides indepth and longitudinal information often missing from survey research and quantitative analysis. These case studies will enhance the understanding of local values, motives, and cultural contexts that shape individual and family decision-making on matters of finance and migration. Though the circumstances of families in these case studies are unique, patterns that emerge out of the data have relevance for the wider population.

\section{THE SRI LANKAN ECONOMY}

Sri Lanka has been integrated into the global economy for centuries through precolonial and colonial trade networks (McGilvray, 1998). Currently Sri Lanka is tied into the global economy through the export of spices and tea, the manufacture of garments and other products in export production zones (Lynch, 1999), tourism, and the migration of labor to the Middle East (M. Gamburd, 2000; Brockmann, 1990, 1992). Sri Lanka is also tied into the international economy through the actions of international financial and development agencies. Although burdened with less international debt than many less developed countries, under instruction by the International Monetary Fund, Sri Lanka has

\footnotetext{
1 "Naeaegama" is a pseudonym for the village in question. Names of villagers have also been changed to preserve the privacy of the informants.

${ }^{2}$ This research was made possible in part by National Science Foundation grant number SBR-9903314.
} 
undergone structural adjustments that devalue its currency, erode its social welfare programs, and open its economy to foreign investment.

Sri Lanka has for many years stood head and shoulders above other countries in the region in terms of general quality of life indicators, which show that the island nation of eighteen million ranks highest in South Asia in terms of literacy, life expectancy, and sanitation, and lowest in terms of infant mortality and population growth (Shah, 1995; Central Intelligence Agency, 1998). The government’s liberal economic policies since 1977 have stimulated trade and investment, and despite nearly two decades of civil strife, Sri Lanka has sustained a creditable rate of economic growth (Arunatilake et. al., 2000: 5). At the same time the gap between the rich and the poor has widened dramatically, and many well-educated youth lack suitable employment.

\section{THE INTERNATIONAL OIL ECONOMY}

The larger context for Naeaegama women's labor migration rests in the international trade of petroleum products. Oil is one of the most important products circulating in the world's economy (Energy Information Administration, 1999). The price of oil is in large part controlled by the actions of the Organization of Petroleum Exporting Countries (OPEC). Five Persian Gulf nations (Saudi Arabia, Kuwait, Qatar, United Arab Emirates, and Iraq) produce a quarter of the world's oil. These countries' control over this vital resource makes them wealthy and powerful players in the global economy. Wealth from the export of oil draws foreigners to work in the Persian Gulf nations. Many oil-exporting countries have grown to rely on guest workers, with over 60 percent of these workers coming from South and Southeast Asia (Addleton, 1991). Workers often send part or all of their wages to their home countries, and worker remittances make up a significant portion of the transnational flow of money. The conjunction of petroleum production and remittances, therefore, forms the economic context within which to analyze Sri Lankan women's work and wage remittance.

The number of Sri Lankans working abroad has increased dramatically over the past decade. In 1990 the figure stood at around 300,000; by 1994 officials set the figure between 300,000 and 500,000; and estimates for 1999 hovered at 800,000 or above (Migration News, 1999). In 1999, 86 percent of Sri Lanka's migrants left for destinations in the Middle East (SLBFE, 2000).

Gender ratios have also changed over time. As demand for construction workers in the Gulf countries dwindled in the early 1980s, demand for domestic servants rose, and women from Indonesia, the Philippines, and Sri Lanka fill these positions. In 1981, 52 percent of Sri Lanka's migrant laborers were female; by 1992 the figure stood at 68 percent, and by 1994 it had risen to 79 percent (Korale, 1983; SLBFE, 1997, table 32). In 1999 the percentage fell to about 65 percent, due not to a reduction in female migration but rather to an increase in the export of male labor (SLBFE, 2000). Currently 9 percent of Sri Lanka's working-age women are employed abroad, most in the Middle East (M. Gamburd, 2000:39).

Migrant women's livelihoods, and those of the families and communities that depend on their remittances in their home countries, are closely tied with the well-being of the oil-exporting countries where they work. Sri Lanka's increasing integration into the international division of labor has brought both advantages and disadvantages.

Providing much needed employment, the global economy also leaves Sri Lankan families 
vulnerable to international developments in politics and economics. The significance of such close connections was dramatically illustrated during the Gulf Crisis of 1990-1991.

\section{THE GULF WAR}

The Gulf Crisis affected nearly every nation on earth either directly or indirectly. On August 2, 1990 Iraq invaded Kuwait, in the process not only drastically disrupting political relations in the Persian Gulf, but also altering worldwide control over a vital energy resource. An international coalition under UN leadership imposed sanctions against Iraq, followed by a six-week war of aerial bombardment, which eventually forced Iraq to withdraw in March 1991. After the war, due to Iraq's refusal to comply with UN weapons inspections, the UN imposed severe economic sanctions that only began to ease in 1996.

Iraq's invasion of Kuwait displaced 5.5 million people, producing a mass movement of refugees to the countries of Saudi Arabia and Jordan (Lelyveld, 1992; Miller, 1991; Ciriaci, 1998). An estimated 2 million guest workers returned to their own countries, including 350,000 Asians (MacLeod, 1991; Miller, 1991). Among these were between 75,000 and 100,000 Sri Lankans. Extensive international relief efforts functioned to feed, shelter, and repatriate refugees.

Countries and individuals not directly involved in the war experienced ripple effects from the crisis. The losses of jobs and savings experienced by displaced guest workers affected the people in sending countries who had depended on remittances. Before the Gulf War, "Third World workers in Iraq and Kuwait sent about \$3 billion (U.S.) a year to their families"(MacLeod, 1991). Households not only lost the income of their breadwinner, they also had to support that person upon his or her return. In addition, families that had gone into debt to send a worker abroad still had to pay back the debt despite unexpected termination of employment. National governments spent a great deal to bring stranded citizens home. Moreover, due to the crisis, oil prices rose dramatically worldwide, affecting not only transportation but also balance of payments of poorer oilimporting countries. Some countries also experienced radically reduced earnings from tourism. Others, such as Sri Lanka, which had sold much of its tea crop to Iraq, found that the war had significantly altered their export markets (MacLeod, 1991). The combination of these factors contributed to inflation and rising unemployment in many countries around the world.

\section{THE UNITED NATIONS COMPENSATION COMMISSION}

In early April 1991, the United Nations Security Council declared that "Iraq...is liable under international law for any direct loss, damage, including environmental damage and the depletion of natural resources, or injury to foreign Governments, nationals, and corporations, as a result of Iraq's unlawful invasion and occupation of Kuwait” (Security Council resolution 687 of 3 April 1991, cited in UNCCS, 2002). The United Nations Compensation Commission, a subsidiary of the UN Security Council, was created in 1991 to "process claims and pay compensation for losses and damages" resulting from the Gulf War (UNCCS, 2002). 
The international community imposed sanctions on Iraq for its failure to comply with UN Weapons inspections. ${ }^{3}$ The sanctions severely restricted the funds available to the UNCC for making compensation payments to successful claimants. In December 1996, sanctions were lifted slightly, and Iraq was allowed to sell oil to buy supplies such as food and medicine. Thirty percent of the proceeds (reduced in 2000 to twenty-five percent) flowed into an escrow account from which the UNCC began the disbursement of compensation money (UNCCS, 2002).

In total, the UNCC received "approximately 2.6 million claims seeking compensation in excess of US\$ 300 billion” (UNCCS, 2002). The UNCC administered claims under six different categories, with priority given to small individual claims (categories A, B, and C) over larger individual claims (category D), claims by corporations (category E), and claims by governments and international organizations (category F) (2002). One analyst views the smaller, individual claims as less complex and less prone to dispute and litigation (Bonner, 1996).

Overall, the UNCC approved ninety-three percent of category A claims and, as of February 2002, it had paid slightly less than US\$ 3.2 billion in compensation to 860,000 successful category A claimants (2002). Sri Lankans filed 92,739 category A claims, with roughly 87,000 receiving compensation. Another 4000 received other sorts of compensation (UNCCS, 2002).

Individuals receiving category A compensation collected a maximum of US\$ 4000. Claim applications were processed between October 1994 and October 1996 (UNCCS, 2002). Initial payments of $\$ 2500$ on category A claims were made in six "instalments” (sic) between March 1997 and July 1999 (UNCCS, 2002). A second phase of payments (\$1500 for individuals) began later that year, and one further payment representing compensation for loss of use of the compensation money during the lengthy delay in payment may be made after the principal payments on all claims in all categories have been completed (UNCCS, 2002). Payments are made as funds build up in the escrow account, and are distributed according to UNCC administrative capacity, the date that the claims were filed, and the geographical distribution among the many different countries in which citizens filed claims (2002). The UNCC sends money for category A claims to national governments, which distribute the funds to successful claimants. Altogether, Sri Lankans have received approximately US\$ 350 million through the UNCC.

\section{NAEAEGAMA}

The eleven case studies in this paper contain qualitative ethnographic data gathered in the village of Naeaegama, where the author, a cultural anthropologist who studies labor migration, gender, and social change, has done fieldwork since 1991. Interviews, discussions, and conversations were conducted in Sinhala, the local language. The author's long-term research associates translated when needed during interviews. A thorough census was performed and a detailed map of the village was developed. The author recorded data concerning the occupants of each household, particularly the

\footnotetext{
${ }^{3}$ Although sanctions have eased over the years with the "Oil for Food" program, the economic situation in Iraq remains grave, with food and medicine in short supply. Much has been written about the horrendous human cost of these sanctions born by the Iraqi people (see for example (Jiuyue 1998, Lapskiy 2000).
} 
migration records of the women. Research also included interviews with officials at the Sri Lanka Bureau of Foreign Employment in the capital city, Colombo. The SLBFE provided extensive documentation of the migration of labor that proved useful in contextualizing village experiences at the national level.

The administrative area of Naeaegama covers a little over one square mile. During the past three decades the population of the area has doubled, from about five hundred people in 1969 (G. Gamburd, 1972: 68) to roughly eleven hundred in 2000. A small number of landholders own paddy fields, coconut gardens, and cinnamon estates. The majority of people own only their small housing plots, which do not provide sufficient acreage to farm either for subsistence or for profit. Available jobs for women and men have not kept pace with population growth, and under- and unemployment are high in the village. Main occupations for women include coconut rope-making, factory work, teaching, assisting their families in cinnamon peeling and broom-making, and domestic service in the Middle East. Main occupations for men include cinnamon peeling, making and peddling brooms, day labor, and work in tourism, security, and the military (see M. Gamburd, 2000:17-18). Rampant inflation has pinched many Naeaegama families hard, challenged their ingenuity, narrowed their choices, and added urgency to their search for viable financial strategies.

Since the early 1980s, women from Naeaegama and other locations in Sri Lanka have increasingly taken jobs as housemaids in the Middle East. Women work abroad on two-year contracts, often returning repeatedly to the Gulf. They pay job agents and moneylenders between US\$ 300-600 to procure their employment, and earn about US\$100 a month. In the early 1990s, three quarters of the migrants were married, and 90 percent of the married women left behind children (Eelens et. al., 1992:6). Since that time, growing numbers of unmarried women have also joined the migrant flow. Much of migrants' earnings are remitted to their families, who often use some or all of this money to support the family's daily consumption. Those without property hope to save enough money to buy land and build a house, and over the past decade new construction has sprung up all over the village. It remains to be seen whether, having fulfilled their stated goals, women will continue to migrate; even families with new houses often find that they cannot subsist without a migrant's remittances. Few housemaids consider their experiences as servants pleasant, and most would prefer to work locally if viable opportunities existed. But in the context of the struggling local economy, many of the nation's families, including a large number in Naeaegama, have grown ever more intimately tied into the global market as the trend in female migration continues.

Local ramifications of the Gulf War and its aftermath dramatically illustrated village integration into the global economy. Iraq's invasion of Kuwait disrupted the employment of thirteen local women (roughly one quarter of Naeaegama's migrant laborers at the time). Between 1997 and 2000, the women received US\$ 4000 as compensation for interruption of employment. This payment, though relatively small from the perspective of those living in industrialized countries, represents a significant sum in the local economy (equal to three and a half years' salary as a housemaid). The compensation money makes a favorable change in a family's finances, and collectively gives a boost to the country as a whole. The remainder of the essay explores what people have done with remittance and compensation money, and how family relations have affected and been affected by these financial decisions. 


\section{ECONOMIC IDEOLOGIES AND THEORIES OF THE FAMILY}

Spread by development agencies and international financial agencies such as the World Bank and the International Monetary Fund, some Western theories about development have suggested in the past that modernization will occur only after a revolution in the traditional attitudes that hamper growth in entrepreneurial risk-taking approaches (Rostow, 1964; Geertz, 1963; Peet and Hartwick, 1999). Western assumptions about individuals as "rational economic beings" still pervade planning policies around the world. These neo-liberal economic theories assume that people act as individuals with unlimited wants who pursue profits in order to maximize individual well-being in a competitive world with scarce resources. Although planners are beginning to recognize 'the human factor' in development projects, much development theory still assumes that individuals will maximize utility and profit without much regard for moral or cultural issues, an equitable distribution of income, or the effects of their actions on the larger social, political, and physical environment (Visvanathan, 1997; Porter, 1995).

The radical political economy perspective shifts the unit of analysis from the individual to the social group, suggesting that individual actors always act in a social and cultural context. As individuals and members of groups, they struggle against others in conflicts over resources, benefits, and decision-making power. Unequal relations between nations reflect colonial and neo-colonial power dynamics (Frank, 1966; Chew and Denemark, 1996). Such theorists suggest that economic, political, and social ideologies circulated by powerful countries and agencies undermine local traditions and social structures, making groups more vulnerable to exploitation (Escobar, 1988; Wolf, 1997).

Feminist anthropologists carry this argument a step further, suggesting that while larger economic and ideological processes influence local traditions, the local also affects the global. For example, gender and region of origin play a role in the international division of labor. In the international labor market, women from less developed and developing countries have progressively taken over low-paid, low-skill service jobs in richer countries (Chang, 2000; Fernandez-Kelly, 1983; Cairoli, 2001). The explanation for this situation lies in part in the actions of large financial institutions such as the International Monetary Fund, with its structural adjustment programs that drain Third World economies, remove most safety nets for the poor, but fail to reduce international debt (Chang, 2000; Schaeffer, 1997). Unable to find jobs at home, female Asian migrants take jobs abroad in order to make ends meet for their families at home (Constable, 1997). These larger economic circumstances create a situation where a seemingly endless supply of poor women will willingly take any job, anywhere, no matter how poorly paid (Harrison, 1997). Gender roles, family priorities, and domestic arrangements both shape and conform to national and international political and economic forces.

A detailed understanding of local dynamics enhances knowledge about larger systems. Researchers concerned with family relations examine unequal power relations not only at the local, national, and international levels, but also within the household, which may itself embody additional hierarchies, particularly those of gender and age (Lockwood, 2001; Sacks, 1989). Normative gender roles and women's positions in household and larger kinship structures shape family decisions regarding migration and the use of money (Yeoh et. al., 1999; M. Gamburd, 1995). Family plays a vital part in 
facilitating successful migration of both skilled and unskilled labor (Shah and Menon, 1999; Shah, 2000). Trends in international migration cannot be fully understood without reference to gender ideologies and family structures in host and sending countries (Tacoli, 1999; Willis and Yeoh, 2000). Researchers gain from contextualizing financial decisions in wider economic, social, and political factors, while preserving a focus on family, household, and gender.

\section{FAMILY USE OF REMITTANCES}

While abroad, female migrant workers rely on their domestic networks to care for their children and keep the home fires burning; thus relatives in poorer countries subsidize the cheap wages migrant women earn in rich host countries. This subsidy does not go without reward; women workers often channel their remittances to support their families. Globally, this compensation for family members is a necessary element in providing the bare minimum of comfort and sustenance for the reproduction of cheap, exportable labor. Without this step in the financial cycle, poor women could not continue to play their current part in the international economy. Family-based spending habits are products of and adaptations to thoroughly modern and globalized contexts, and family structures in labor-exporting countries both affect and reflect global realities.

In Naeaegama, families enable migration; in return, migration and remittances affect families. Migration often enhances reliance on the extended family (M. Gamburd, 1998). For example, Winitha (the migrant in case 1) left her four children in her motherin-law's care when she went abroad. Similarly, the migrant in case 8 left her three children with her mother, Sumitha, on repeat journeys abroad. In an interview, Sumitha said that she could charge 2000 rupees (US\$ 20) a month for the work she did for her daughter; over the many years, this would have added up to a large sum of money. Since the family is poor, however, she has not asked for anything beyond support toward subsistence. In return, she expects that she will continue to live in her daughter's household in her old age. Sumitha owns the land on which her daughter's modest but comfortable house is built and makes rope to bring in a small income of her own. In both cases, support from the extended family makes female migration possible, and in return the migrant channels finances back into the household.

Longitudinal research on Naeaegama households receiving the minimal remittances of housemaids' salaries suggests a slow but perceptible improvement in family finances. Migrants' families often carry significant interest-bearing debts in the village, and incur further debt to send the migrant abroad. For example, the migrant in case 5 borrowed money using her mother-in-law's land as collateral to finance her first trip abroad - a trip to Kuwait that was interrupted by the Gulf War. Paying back debts while supporting a family leaves little surplus for savings. In this migrant's case, the family struggled to repay the debt and save their land from the moneylender without any contributions from her remittances. In fact, since they did not hear from the migrant for several months after Iraq's attack, the family feared she had been killed in the war. Upon her return, the family used her minimal savings to repay their debt. In this situation the family eventually received ample compensation for interrupted employment through the UNCC; in many other cases where migrants return prematurely from their work abroad, the family must repay any remaining debts as best they can. The specter of this sort of financial hardship can force women to endure extremely unpleasant jobs abroad. 
Both official analyses and local knowledge suggest that housemaids often spend much of their salary for their families' daily consumption (Gunatilleke, 1992, 1995). Often these families chose to send a woman to the Middle East in the first place precisely because local employment could not adequately support the family. For example, Winitha, the migrant in case 1 , said that her family expenses were high. When she worked abroad, her remittances went in part to settle food bills. Though not the preferred use of remittance money, channeling wages toward consumption fulfills a necessary function and meets one of the migrant's goals for family well-being.

Women often have to migrate repeatedly before they can finance improvements such as buying land, building houses, and starting businesses. In Naeaegama over the ten years between 1990 and 2000, many local households, including all of the case study families, have significantly reduced their debts and improved their housing conditions due to migrant remittances. Although it might take four to six years for signs of progress to become visible, migrant women and their families do over the course of a decade achieve significant improvements in their economic situations.

\section{BARRIERS TO RURAL SELF-EMPLOYMENT}

If possible, family members usually seek local employment opportunities before pursuing jobs abroad. Lucrative enterprises, however, are scarce. Seeking to alleviate poverty, numerous governmental and non-governmental organizations have worked to promote self-employment schemes in rural Sri Lanka. Nevertheless, barriers to sustainable development through small-scale entrepreneurship persist (Woost, 1997). Dias and Sanmugam (1993) identify a number of constraints on potential selfemployment and rural development in Sri Lanka, including:

- Lack of entrepreneurial skills among the target population

- Lack of gender-appropriate, year-round, entrepreneurial options

- Lack of technical know-how

- Lack of management skills

- Lack of literacy and book keeping skills

- Lack of knowledge for how to market products in a competitive environment

- Lack of child care facilities

- Lack of land and buildings to run a business

In a study of families involved in a self-employment program initiated to provide affordable credit for men and women displaced by the Gulf War, Dias and Sanmugam found that most of these households lost their business capital due to family financial crises, production problems, and previously incurred debts to moneylenders (1993). Families in Naeaegama operate under the constraints listed above when making decisions about how to spend or invest their wages and the compensation money they receive through the UNCC. For example, before she received compensation money, Rani, (the migrant in case 3) had purchased a trishaw (3-wheeled, covered motorcycle with seating for 3 passengers) for her husband using money she earned abroad. While driving this vehicle as a taxi, her husband, Wijepala, was almost killed in a collision with a bus. Since the other driver was at fault, the bus owner's insurance paid for the damage. With 
the insurance money, the couple bought another three-wheeler. A year later, an inebriated, uninsured acquaintance wrecked the second vehicle. Rani and Wijepala sold the damaged trishaw at a loss. Since then, they have not invested in business ventures. Noting that she had lost the trishaw and nearly lost her husband, Rani asserted, "One should buy land and build with Middle East money; other undertakings just don't go right!” Though hampered by lingering injuries from his accident, her husband makes an adequate income as a mason.

Development analysts suggest that introducing money into the formal banking system counts as a good option. Some migrants do keep their money in the bank. For example, Ruwanitha (the migrant in case 6) sent some of her remittances home; her parents purchased two plots of land for her. She saved some of her remittances and all of her compensation money in the bank. With the current rates of inflation and devaluation, however, money saved in rupees quickly depreciates, and money invested in business must generate significant returns merely to reproduce the principal. Given the particulars of women's lives and the constraints inherent in the system, a financial strategy favoring savings, investment, and self-employment is not necessarily a family's best option. Women and their families carefully invest money in areas that they feel will give a lasting benefit and a relatively sure return.

\section{NAEAEGAMA PRIORITIES FOR THE USE OF KUWAIT COMPENSATION MONEY}

Although most of the thirteen Naeaegama women who were working in Kuwait when Iraq invaded in 1990 feared that the promised compensation would never materialize, after a nearly six-year delay the long-awaited money finally began to arrive. Kuwait returnees received US\$ 4000 in two installments dispensed in six rounds each, the first dispersed between 1997 and 1999, and the second between 1999 and 2000. ${ }^{4}$ Most of these families had had women working for a number of years in the Middle East, both before and sometimes after the Gulf War. The families had achieved a certain level of well-being in terms of freedom from debt. While migrants consider using remittances for daily consumption and the education of children as worthwhile uses of money, they also hope to save enough to purchase land and build a house, or make another large, onetime investment for the future benefit of the family. Like carefully saved remittance money, compensation received by Naeaegama women from the UNCC provides an opportunity to investigate what sorts of financial choices migrant women and their families make when they have funds above and beyond those needed for daily subsistence.

Overall, the families of the eleven individuals interviewed used their compensation money for something productive (see Table 1), and implicitly conformed to a clear hierarchy of local goals and objectives for governing decisions (see Figure 1).

\section{(Place flow-chart, 'Figure 1,’ near here)}

\footnotetext{
${ }^{4}$ The women received slightly different rupee amounts, reflecting the different exchange rates in operation at the times of payment. For the first compensation payment, with the exchange rate between Rs. 60/ and Rs. 70/ per dollar, US\$ 2500 netted between Rs. 150,000/ and 175,000/. In 2000, with the exchange rate hovering near Rs. 72/ per dollar, the second compensation payment of US\$ 1500 netted approximately Rs. $108,000 \%$.
} 
Families' first priority was to buy land and build a house if they did not already have these. Including Rani and Winitha (cases 1 and 3, discussed above), four of the eleven families interviewed had invested in housing (cases 1-4 on Table 1). Only under unusual circumstances did people without these assets not procure them. For example, one childless couple (case 5) had been asked by their relatives not to move out of the family house (inhabited by the husband's unmarried brother and mother). They had not purchased land or built a house, but had not yet done anything else with their money, which they had saved in a bank. Ruwanitha, the unmarried woman discussed above, owned two plots of land and had money in the bank, but had not started construction on a house (case 6). Her family already had a large dwelling and did not need more space, otherwise they would have used her money for construction. Local gender norms prohibit respectable single women from living alone unless they wish to forfeit their good reputation and any chance of an arranged marriage. Ruwanitha could not build a house with her money until she married or found male relatives to share the living-space with her. In the meantime, she stayed with her parents' household.

Families who already owned land and houses (often built or improved with money remitted from abroad during repeat migrations) spent money on a second priority. Unmarried women saved or used their money for their own dowries, while married women with unmarried daughters banked their funds to use for their daughters' dowries and weddings. Ruwanitha's sister used her compensation money for her own dowry (case 7), and Ruwanitha could potentially use her savings for the same purpose (case 6). Sumitha's daughter was saving her money for her own daughters' dowries (case 8) while another Kuwait returnee planned to bank money for this cause when she received it (case 9).

Local people see dowry and wedding expenses as a productive investment of resources. In this region of Sri Lanka, families seeking to arrange marriages for daughters offer dowries to families of potential grooms. Forming strategic alliances through marriage constitutes a significant aspect of a family’s social status (de Munck, 1996). In addition, finding a husband with a job assures the financial well-being and security not only of the bride but potentially for her whole family. Marrying a daughter to a good man (one who has a steady job, a solid education, powerful relatives, or a significant amount of property) serves as a forward-thinking move in local survival strategies. Since a large dowry increases a woman's chance of attracting a good husband, investing money in a dowry is a local family priority.

Only women who already owned land, had finished construction on their houses, and did not have to worry about their daughters' dowries invested money in business. One woman, Sepali, (with a one-year-old son) purchased land and a house with the first installment and purchased a fishing boat and net with the second (case 10). Her husband's family were experienced fishermen, but had previously lacked the capital to purchase a boat. Another woman, Kanti, (with a house and land, no daughters, and three grown sons) had purchased a small cinnamon garden with the first installment of compensation money (case 11). Kanti's husband, a cinnamon peeler, could make a good income from the harvest, and her sons could in the future use the land for housing. With the next installment, she was considering buying more cinnamon land or a trishaw for 
one of her sons to use as a taxi. Land ownership and steady employment would add to the family coffers and increase the sons' likelihood of attracting brides with good dowries.

(Place Table 1 near here)

The information presented above and in Table 1 suggests that Naeaegama women and their families share a very clear hierarchy of goals and objectives. Significantly, none of the women interviewed planned to save her compensation money for future daily consumption, though several continued to work either in Sri Lanka or abroad to support their families' everyday needs, including the education of children. The first priority is land and housing. The second is one's own or one's daughters' dowries. People address the third priority, investments in business ventures, only after the other two are satisfied. Only when they have secured housing and have fulfilled marriage responsibilities will women invest in productive enterprises, and then only in business ventures about which they already possess sufficient knowledge to be successful, as illustrated by Kanthi's cinnamon peeling family's purchase of cinnamon land and Sepali's fishing family's purchase of a boat and net.

\section{FAMILY DECISION-MAKING PROCESSES}

Data gathered in Naeaegama contribute to conclusions concerning the role of family and gender in household economic decisions. Although priorities for spending Kuwait Compensation money emerge clearly from the eleven cases discussed above, families do not always agree on how to use their money, and decision-making processes do not always run smoothly. Individuals find themselves situated in unequal power relations not only at the international level but also within the household. Hierarchies based on age and control over money combine with gender roles to affect an individual's say in family choices about the use of money.

Norms governing practices and duties to larger kinship structures affect the strategies family members employ regarding marriage. Parents and other relatives strive to organize socially and economically advantageous matches for young men and women. Complex negotiations concerning the exchange of land, goods, and money surround an arranged marriage. Contrary to Western sensibilities, arranged marriage represents an ideal to some in the younger generation, and many children hope that their parents will find them a match (Nanda, 1992). But a strong tendency toward romantic or 'love' marriages now coexists in Naeaegama with older traditions of matrimony. Occasionally a youth falls in love and elopes with someone not of the family's choosing, throwing the elders' plans into chaos. Parents on both sides often cut social and financial ties with the disobedient couple, at least until the birth of the first grandchild. In a 'love marriage,' families do not exchange dowry, and love marriages do not create the sort of long-term financial and social responsibility to the extended family that arranged marriages do. For example, Kanti (case 11) hoped that buying her son a trishaw taxi would increase the chances of arranging a marriage with a good dowry. Her son, much to the family's distress, ran off with a penniless bride. By defying their parents, eloping sweethearts move against hierarchies of age and wealth, make decisions based on a heterodox set of priorities, and alter the nature of local kinship structures and practices. 
Gender and family norms also govern how married couples spend their scarce resources. Despite sharing general priorities, husbands and wives often disagree on how to allocate money in practice. For example, during one informal interview, friends and neighbors gathered while the researcher spoke with Winitha, the migrant woman in case 1. Winitha, a very poor woman with an alcoholic husband and four young children, had migrated repeatedly to the Middle East after her first trip abroad ended during the Gulf War. When interviewed in 2000, she was living in an unfinished cement house that was a vast improvement over the dilapidated clay hut she and her family had inhabited in 1992.

Tensions abounded between Winitha and her husband over how they should use remittances and compensation money. With money from Winitha's repeated migrations to the Middle East, plus money received from the UNCC, the family had built a house on Winitha's mother-in-law's property. When asked how she had spent her remittances, Winitha said that she sent some money home to her husband, who paid off loans and bought food for the house. The group of women who had gathered during the interview suggested, laughing and joking, that in addition to taking care of family needs, Winitha's husband had also "landed some" (drank to excess.) Winitha then heatedly but resignedly insisted that she had not wasted any of her money, and that her new house was a concrete sign of all she had done for her family. When asked if the family would be able to finish the house construction and meet their consumption needs on the money that her husband made peeling cinnamon, she replied with frustration that with her husband working and drinking, they were ceaselessly in debt to the local shop, which sold them food on credit. With four children in school, their expenses were very high. She felt that either she would have to go back to the Middle East to earn more money to finish the house, or the children would have to complete it when they start to work. "At least," she concluded, "Now we don't get wet when it rains." In this case, gender norms surrounding the consumption of alcohol (Gamburd, 2000: 177-181) and arrangements concerning the control over remittances resulted in spending decisions that did not fully conform to Winitha's priorities.

Village families agreed that money needed careful handling to ensure that it profited the family. Projects such as buying land, building or repairing a house, providing dowries for oneself or one's daughters, and investing in a business venture all counted as worthwhile uses of money. Families in principle tried to avoid using remittance and compensation money for ordinary consumption. Although family spending generally conformed in its larger outlines to a clear set of priorities, in practice, however, decisionmaking was sometimes fraught with conflicting interests.

\section{CONCLUSIONS}

Family cooperation is key to enabling female migration and facilitating the successful investment of money that women remit or receive as compensation from the UNCC. In Naeaegama, family choices for spending Kuwait Compensation money reveal a clear hierarchy of local goals and objectives. All three priorities (buying land and building a house, providing a dowry, and starting a business) reveal strongly familybased considerations, and use of the money illustrates the family's role as an economic as well as a social unit.

The global economy clearly shapes and affects family dynamics. Although individuals choose where and when to work and how to spend their money, their 
decisions are thoroughly rooted in unequal national and international economic relations. Family priorities draw on patterns of gendered behavior and family association, but reflect and grow out of current adaptations to the modern condition of migration and poverty. Simultaneously, family dynamics clearly affect larger migratory patterns: family considerations determine which people migrate, what jobs they do, and the sorts of wages they are willing to accept, all of which are matters of importance for macro-level analysis of the global economy.

Discussion of family involvement in migration provides a critique of the inequality in the current global economic system. Women's migration affects an international redistribution of reproductive labor, and reflects and contributes to the general feminization of the working class on a global scale. Despite years of hard work abroad, many Sri Lankan women still struggle to provide enough money for their family's basic needs. The push factors from Sri Lanka involve the liberalized economy and lack of local jobs for men or women, which drive women to migrate to the Middle East. Pull factors in the Middle East include wealth generated by the sale of petroleum products, a desire for leisure time among the local population, and the need to hire a housemaid, which has become a status symbol in the Middle East. Migrant women have assumed the burden of boring, difficult, repetitious domestic labor in the Persian Gulf, while family members in the sending countries take over women's domestic labor in the homes they leave. Family cooperation in the sending country is a necessary condition for the migrant to be able to leave, and family responsibilities compel women to accept wages at rock-bottom levels in the world market. 


\section{REFERENCES CITED}

Addleton JS. 1991. The impact of the gulf war on migration and remittances in Asia and the Middle East. International Migration 29: 509-526.

Arunatilake N, Jayasuriya S, Kelegama S. 2000. The Economic Cost of the War in Sri Lanka. Institute of Policy Studies: Colombo.

Bonner R. 1996. A payoff for lives twisted by Gulf War. New York Times. 17 December 1996.

Brockmann G. 1990. The Middle East Avenue: Female Migration from Sri LankaCauses and Consequences. Oslo: Institute for Social Research.

-----. 1992. Sri Lankan housemaids in the Middle East: an avenue for social and economic improvement? In Labor Migration to the Middle East: From Sri Lanka to the Gulf. Eelens F, Schampers T, and Speckmann JD (eds): Kegan Paul International: London: 215-37.

Cairoli ML. 2001. Factory as home and family: female workers in the Moroccan garment industry. In Gender in Cross-Cultural Perspective, Brettell C, Sargent C (eds): Prentice Hall: Upper Saddle River, NJ: 551-564.

Central Intelligence Agency. 1998. World Factbook 1998. http://www.odci.gov/cia/publications/factbook/index.html, 16 August 1999.

Ciriaci F. 1998. Jordan: Officials cited on Iraq crisis, 'Precautionary Measures'. Amman Jordan Times (Internet Version) in English. 2 February 1998.

Chang G. 2000. Disposable Domestics: Immigrant Women Workers in the Global Economy. South End Press: Cambridge, MA.

Chew SC, Denemark RA. 1996. The Underdevelopment of Development: Essays in Honor of Andre Gunder Frank. Sage Publications: London.

Constable N. 1997. Made to Order in Hong Kong: Stories of Filipina Workers. Cornell University Press: Ithaca, NY.

De Munck VC. 1996. Love and marriage in a Sri Lankan Muslim community: Toward a reevaluation of Dravidian marriage practices. American Ethnologist 23: 698-716.

Dias M, Sanmugam T. 1993. An Evaluation Report: A Credit Programme for Kuwaiti Returnees. Centre for Women's Research (CENWOR): Colombo, Sri Lanka.

Eelens F, Mook T, Schampers T. 1992. Introduction. In Labor Migration to the Middle East: From Sri Lanka to the Gulf. Eelens F, Schampers T, Speckmann JD (eds): Kegan Paul International: London: 1-25.

Escobar A. 1988. Power and visibility: Development and the invention and management of the Third World. Cultural Anthropology 3: 428-443.

Energy Information Administration. 1999. OPEC Revenue Fact Sheet [May 1999] http:// www.eia.doe.gove/emeu/cabs/opecrev.html, 26 July 1999.

Frank AG. 1966. The development of underdevelopment. Monthly Review 18: 17-31.

Gamburd G. 1972. The Seven Grandparents: Locality and Lineality in Sinhalese Kinship and Caste. Ph.D. diss., Columbia University.

Gamburd M. 1995. Sri Lanka's 'army of housemaids': Control of remittances and gender transformations. Anthropologica 37: 49-88.

-----. 1998. Absent women and their extended families: Sri Lanka’s migrant housemaids. In Negotiation and Social Space: A Gendered Analysis of Changing Kin and 
Security Networks in South Asia and Sub-Saharan Africa. Risseeuw C, Ganesh K (eds): Sage: New Delhi: 276-91.

-----. 2000. The Kitchen Spoon's Handle: Transnationalism and Sri Lanka’s Migrant

Housemaids. Cornell University Press: Ithaca, NY.

Geertz C. 1963. Peddlers and Princes: Social Development and Economic Change in Two Indonesian Towns. University of Chicago Press: Chicago.

Gunatilleke G (ed). 1992. Sri Lanka. In The Impact of Labour Migration on Households: A Comparative Study in Seven Asian Countries. Gunatilleke G (ed): United Nations University Press: Tokyo: 227-263

-----. 1995. The economic, demographic, sociocultural and political setting for emigration from Sri Lanka. International Migration 33: 667-698.

Harrison FV. 1997. The gendered politics and violence of structural adjustment. In Situated Lives: Gender and Culture in Everyday Life. Lamphere, Ragone, Zavella (eds): Routledge: New York: 451-468.

Jiuyue S. 1998. A sad scene in sanction-hit Iraq. Beijing Xinhua in English. 1 March 1998.

Korale RBM. 1983. Migration for Employment to the Middle East: Its demographic and socio-economic effects in Sri Lanka. Ministry of Plan Implementation: Colombo.

Lapskiy V. 2000. How to break free from vicious circle. Moscow Rossiyskaya Gazeta 20 Aug 2000.

Lelyveld MS. 1992. Middle East experts weigh effect of labor mobility on economies. Journal of Commerce, 18 February 1992.

Lockwood VS. 2001. The impact of development on women: The interplay of material conditions and gender ideology. In Gender in Cross Cultural Perspective, Brettell C and Sargent C (eds): Prentice Hall: Upper Saddle River, NJ: 529-541

Lynch C. 1999. The 'good girls' of Sri Lankan modernity: moral orders of nationalism and capitalism. Identities: Global Studies in Culture and Power 6: 55-89.

MacLeod K. 1991. Third World pays price of war: fallout from Gulf conflict rocks economies of poor nations. Toronto Star, 2 April 1991.

McGilvray DB. 1998. Arabs, Moors and Muslims: Sri Lankan Muslim ethnicity in regional perspective. Contributions to Indian Sociology, ns. 32: 433-83.

Migration News. 1999. Sri Lanka, Pakistan. 6 (10), January. http://migration.ucdavis.edu/Archive/jan_1999-27.html, 6 May 1999.

Miller J. 1991. Displaced by Gulf War: 5 million refugees. New York Times, 16 June 1991.

Nanda S. 1992. Arranging a Marriage in India. In The Naked Anthropologist, Devita PR (ed): Wadsworth Publishing Company: Belmont, CA: 34-45.

Peet R, Hartwick E. 1999. Theories of Development. Guilford Press: New York.

Porter, DJ. 1995. Scenes from childhood: The homesickness of development discourses. In Power of Development. Crush J (ed): Routledge: London: 63-86.

Rostow WW. 1964. The takeoff into self-sustained growth. In Social Change: Sources, Patterns, and Consequences. Etzioni, Etzioni (eds): Basic Books Inc: New York: 275-290.

Sacks K. 1989. Towards a unified theory of class, race and gender. American Ethnologist 16: 534-49. 
Schaeffer RK. 1997. Understanding Globalization: The Social Consequences of Political, Economic and Environmental Change. Rowman and Littlefield Publishers, Inc.: New York.

Shah NM. 2000. Relative success of male workers in the host country, Kuwait: does the channel of migration matter? International Migration Review 34: 59-79.

Shah NM, Menon I. 1999. Chain migration through the social network: experience of labour migrants in Kuwait. International Migration 37: 361-82.

Sri Lanka Bureau of Foreign Employment (SLBFE). 1997. Statistical Handbook on Foreign Employment. Sri Lanka Bureau of Foreign Employment: Colombo, Sri Lanka.

-----. 2000. Departures for Foreign Employment in 1998. Photocopied manuscript.

Tacoli C. 1999. International migration and the restructuring of gender asymmetries: continuity and change among Filipino labor migrants in Rome. International Migration Review 33: 658-83.

United Nations Compensation Commission Secretariat (UNCCS). 2002. “The United Nations Compensation Commission.” [2 January 2002]. http://www.unog.ch/uncc/start.htm. 21 January 2002.

Visvanathan N. 1997. General introduction. In The Women, Gender \& Development Reader. Visvanathan N, Duggan L, Nisonoff L, Wiegersma N (eds): Zed Books: London: 1-6.

Willis KD, Yeoh BSA. 2000. Gender and transnational household strategies: Singaporean migration to China. Regional Studies 34: 253-64.

Wolf, ER. 1997. Europe and the People Without History. University of California Press: Berkeley.

Woost, MD. 1997. Alternative vocabularies of Development? 'Community' and 'participation' in development discourse in Sri Lanka. In Discourses of Development: Anthropological Perspectives, Grillo RD, Stirrat RL (eds): Berg: Oxford: 229-254.

Yeoh BSA, Huang S, Gonzalez J. 1999. Migrant domestic female workers: debating the economic, social, and political impacts in Singapore. International Migration Review 33: 114-37. 


\begin{tabular}{|c|c|c|c|c|}
\hline $\begin{array}{l}\text { Case } \\
\#\end{array}$ & Land and House & Dowry & Bank & Business \\
\hline 1 & Spent on house & & & \\
\hline 2 & Spent on house & & & \\
\hline 3 & Spent on house & & & \\
\hline 4 & Spent on house & & & \\
\hline 5 & $\begin{array}{l}\text { Living with mother-in- } \\
\text { law }\end{array}$ & (No children) & Money in bank & \\
\hline 6 & $\begin{array}{l}\text { Owns land; cannot } \\
\text { build house to live } \\
\text { alone because } \\
\text { unmarried }\end{array}$ & Unmarried & $\begin{array}{l}\text { Money in bank for } \\
\text { her own dowry or } \\
\text { building a house }\end{array}$ & \\
\hline 7 & $\begin{array}{l}\text { Living at husband's } \\
\text { family home }\end{array}$ & $\begin{array}{l}\text { Used money for her } \\
\text { own dowry }\end{array}$ & & \\
\hline 8 & Owns land and house & $\begin{array}{l}\text { Saving for daughters' } \\
\text { dowries }\end{array}$ & Money in bank & \\
\hline 9 & Owns land and house & $\begin{array}{l}\text { Saving for daughters' } \\
\text { dowries }\end{array}$ & $\begin{array}{l}\text { Awaiting } \\
\text { compensation } \\
\text { money }\end{array}$ & \\
\hline 10 & $\begin{array}{l}\text { Spent on land and } \\
\text { house }\end{array}$ & (One-year-old son) & & $\begin{array}{l}\text { Bought fishing boat } \\
\text { and net }\end{array}$ \\
\hline 11 & Owns land and house & (Three grown sons) & & $\begin{array}{l}\text { Bought cinnamon } \\
\text { land; considering } \\
\text { buying trishaw. }\end{array}$ \\
\hline
\end{tabular}

Table 1: Use of Kuwait Compensation Money in Naeaegama, Sri Lanka 
Gamburd: Figure 1 (flowchart)

I had a very, very difficult time trying to create a computerized version of this flow chart.... Below please find my best (but very unbeautiful) attempt. I have also included the text for the flow-chart in case you have any better luck making this look pretty....

Text for flowchart:

Does the family own land?

No $\rightarrow$ buy land (or save money to do so)

Yes $\rightarrow$

Does the family have an adequate house?

No $\rightarrow$ build a house (or extend a small one, or save money to do so)

Yes $\rightarrow$

Is the migrant married?

No $\rightarrow$ use money for dowry (or save money to do so)

Yes $\rightarrow$

Are the migrant's daughters married?

No $\rightarrow$ use money for dowry (or save money to do so)

Yes $\rightarrow$

Does a family-member have entrepreneurial skills?

No $\rightarrow$ (?) develop skills (or bank money until ready to use)

Yes $\rightarrow$ invest in capital for enterprise

Figure 1: Decision-making flowchart for use of Kuwait Compensation Money in Naeaegama

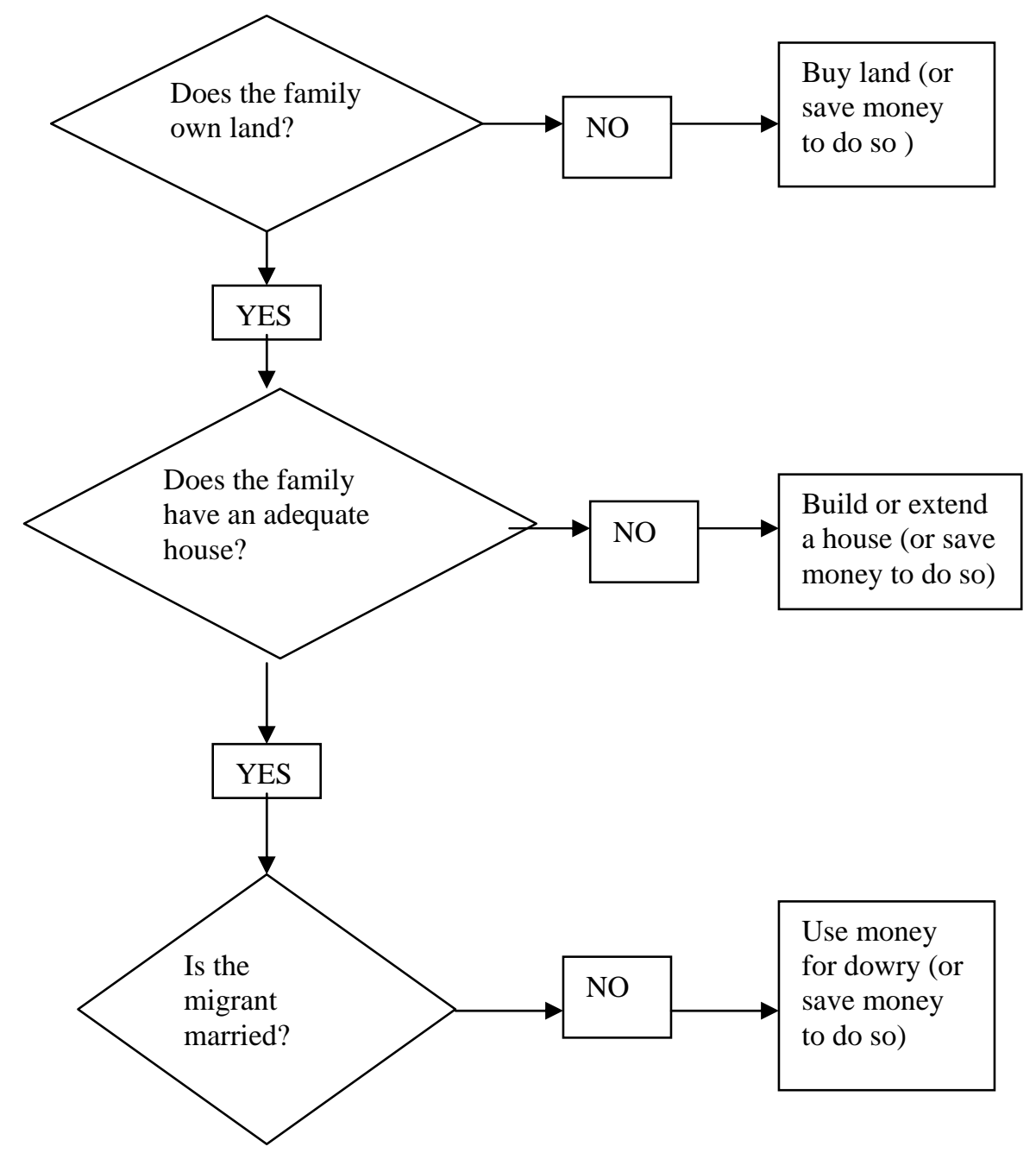




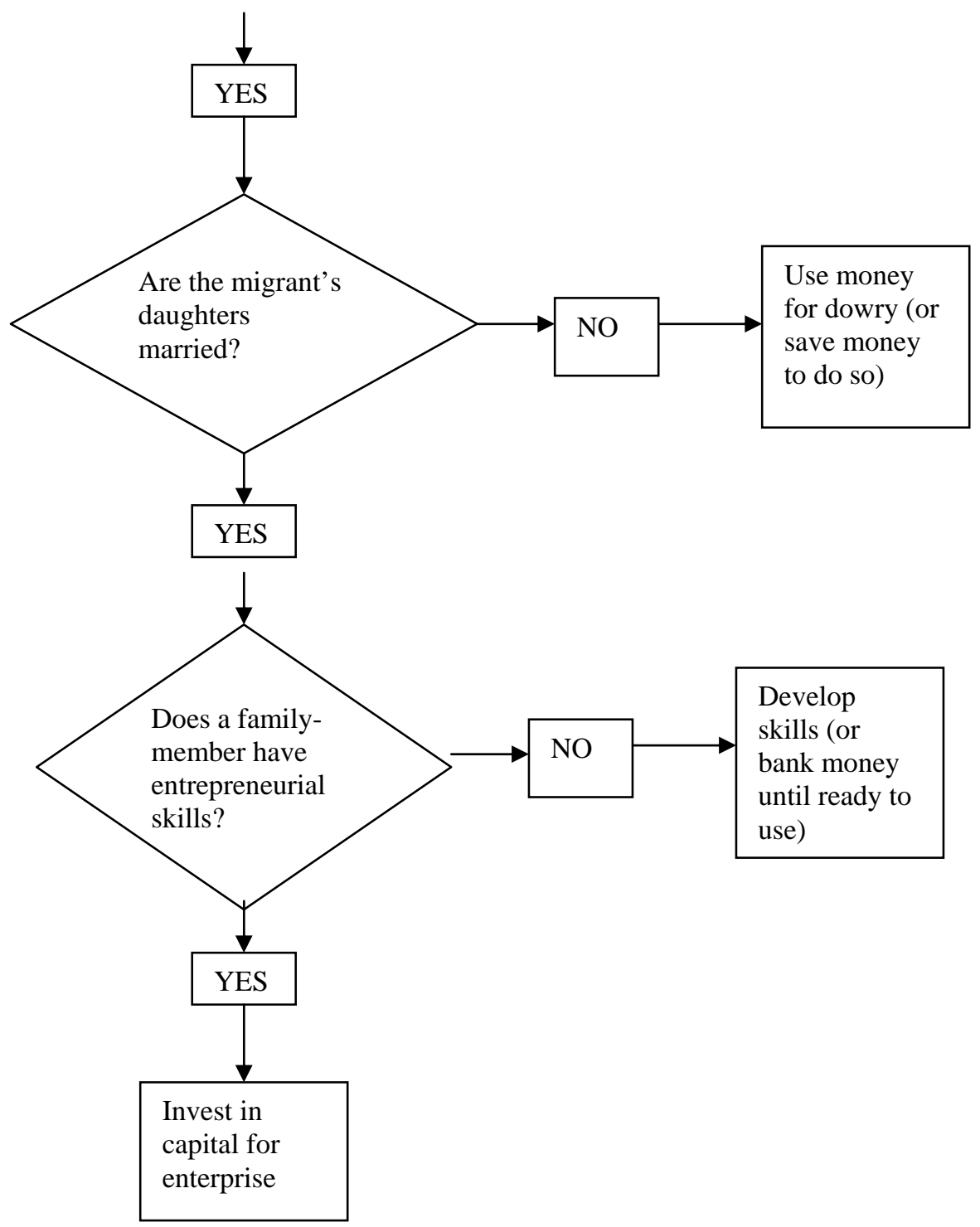

